\title{
Failure to Run on Battery
}

National Cancer Institute

\section{Source}

National Cancer Institute. Failure to Run on Battery. NCI Thesaurus. Code C62990.

Problem associated with the device failing to operate when not connected to a fixed power source. 